Gadjah Mada International Journal of Business

September 1999, Vol. 1, No. 2, pp. 113-132

\title{
THE PREDICTIVE ABILITY OF EARNINGS VERSUS CASH FLOW DATA TO PREDICT FUTURE CASH FLOWS: A FIRM-SPECIFIC ANALYSIS*1
}

\author{
Supriyadi
}

This study evaluated the value-relevance of accounting information (earnings and cash flows) in Indonesia to predict a firm's future operating cash flows. The predictive usefulness of earnings and cash flows in association with future cash flows is of interest for three reasons. They include providing empirical evidence on the relevant accounting information to assess a firm's future cash flows, information about the behavior and properties of Indonesian accounting information, and evidence of - or at least providing a basis for evaluating-the validity of the Indonesian Accounting Standards Committee (KPSAK) assertion on the usefulness of accounting information to assess future cash flows.

The study evaluated three cash flow prediction models that employed cash flow, earnings, and a combination of earnings-cash flow variables. The models were applied on a firm-specific data set. The data used in this study were semi-annual data for the 61 sample firms (manufacturing firms) listed in the Jakarta Stock Exchange (JSX) spanning the years 1990-1997. The results of this study supported the proposed hypothesis that cash flow data provided better information to assess a firm's future cash flows than

\footnotetext{
* This paper is part of my dissertation from the University of Kentucky, U.S.A. I would like to thank my committee members, Professors Michael G. Tearney, James A. Knoblett, Mukhtar M. Ali, Steve J. Ott, and, especially, Stuart B. Keller (Chair), for their thoughtful comments and suggestions. This paper has been presented in the Simposium Nasional Akuntansi II (SNA II), September, 24-25, 1999 in Malang, Indonesia.

${ }^{1}$ The term "cash flows" used in this study refers to cash flows from operations. This term is used interchangeably with the terms of "cash flows from operations" and "operating cash flows."
} 
earnings data. Since this study employed manufacturing firms only, future research is necessary to evaluate the robustness of the results to other populations of firms and/or by using an alternative deflator of earnings and cash flows, such as consumer price index (CPI) or market value of the firms.

Further extensions of this study include additional refinements of the prediction models on an industry-specific basis and disaggregating cash flow variables into operating, investing, and financing components in order to measure the value-relevance of the statement of cash flows.

Keywords: accounting information; cash flows; earnings; future cash flows

\section{Introduction}

In September 1994, the Indonesian Accounting Standards Committee (KPSAK) issued a new set of accounting standards called "Pernyataan Standar Akuntansi Keuangan (PSAK)." The new set of accounting standards (PSAK) replaced the 1984 Indonesian accounting standards called "Prinsip Akuntansi Indonesia (PAI) 1984." These new standards were wholly adopted from the International Accounting Standard (IAS) released by the International Accounting Standard Committee (IASC). In general, the purpose of issuing PSAK was to harmonize Indonesian accounting standards with IAS and to respond to world globalization since it was believed by KPSAK that IAS was acceptable worldwide [Indonesian Accountants' Association (IAI) in PSAK 1995, Sambutan Ketua Umum].

The primary objective of accounting information stated in the Framework for the Preparation and Presentation of Financial Statements in Indonesia is to provide useful information for assessing the amounts, timing, and uncertainty of pro- spective cash flows to the firm [para. 14, and SFAC \#1]. The FASB in SFAC \#1 asserts that "the objectives of financial reporting are not immutable-they are affected by the economic, legal, political, and social environment in which financial reporting takes place."

Some studies that evaluate the effects of economic and social environmental factors on accounting standards find evidence supporting this assertion (Cooke and Wallace 1990; Ndubizu 1992; Doupnik and Salter 1995). They find that cultural and economic differences result in differences in how investors and other financial statement users value the same piece of accounting information. In other words, it is highly possible that the same reporting objective could be achieved using different types of accounting information due to different economic and environmental factors. Hence, empirical results found in the U.S. that support the FASB's assertion that earnings provides better information to assess future cash flows than cash flow itself, may not apply to Indonesia. ${ }^{2}$ All of these conditions lead to the following research questions:

\footnotetext{
${ }^{2}$ Since Ball and Brown's (1968) study in the evaluation of accounting income numbers, there have been many studies that evaluate the usefulness or information content of earnings (Beaver and Dukes 1972; Beaver et al. 1982; Hughes and Ricks 1987; Lev 1989; Kothari and Zimmerman 1995; among others). Under the CAPM, these studies implicitly support the FASB assertion that earnings provide better information to assess future cash flows than cash flow itself.
} 
Suprivadi-ThePredictiveAbility ofEarningsvsCashFlowDatatoPredictFutureCashFlows

What type of accounting information in Indonesia is most useful to investors in assessing a firm's future cash flows?

Does earnings provide more information than cash flows to predict an Indonesian firm's future cash flows?

This study evaluated the value-relevance of accounting information (earnings and cash flows) in Indonesia to predict a firm's future operating cash flows. The predictive usefulness of accounting information in association with future cash flows is of interest for three reasons. They include providing empirical evidence on the relevant accounting information to assess a firm's future cash flows, information about the behavior and properties of Indonesian accounting information, and evidence of - or at least providing a basis for evaluating - the validity of the Indonesian Accounting Standards Committee (KPSAK) assertion on the usefulness of accounting information to assess future cash flows.

The study evaluated three cash flow prediction models that employed earnings and cash flow variables extracted from Indonesian companies' financial statements. The models were applied on a firmspecific regression of the financial data from selected Indonesian firms. The data used in this study were semi-annual data for the 61 sample firms (manufacturing firms) listed in the Jakarta Stock Exchange (JSX) spanning the years 1990-1996. Three sets of accounting information that had been widely used in the U.S. studies to evaluate the value-relevance of accounting information to assess a firm's future cash flows (the FASB's assertion) were used in this study. They include earnings, cash flows, and a combination of earnings and cash flows (Greenberg et al. 1986; Finger 1994; Lorek and Willinger 1996; among others).

The results of this study supported the proposed hypothesis that cash flow data provided better information to assess a firm's future cash flows than earnings data. The result indicated that cash flows significantly provided extra information over and above earnings for 59 percent of the sample firms while earnings was significantly found in 25 percent of the sample firms. In terms of the predictive ability, cash flow and earnings combined exhibited the lowest MAPE (Mean Absolute Percentage Error) and significantly dominated the earnings model but not the cash flow model. Furthermore, this result also indicated that the effects of seasonal factors on future cash flows were more severe than those of adjacent factors.

Since this study employed manufacturing firms only, future research is necessary to evaluate the robustness of the results to other populations of firms and/or by using an alternative deflator of earnings and cash flows, such as consumer price index (CPI) or market value of the firms. Further extensions of this study include additional refinements of the prediction models on an industry-specific basis and disaggregating cash flow variables into operating, investing, and financing components in order to measure the valuerelevance of the statement of cash flows.

The remaining part of this paper is organized as follows. Section II describes the prior studies on the predictive ability of earnings and cash flows. Section III discusses hypothesis development and Section IV describes cash flow forecasting models. Sections V and VI discuss the empirical results and hypothesis tests, respectively. Finally, Section VII concludes the paper. 


\section{Prior Studies}

TheFASB contends that accrual earnings information provides better information for prediction of future cash flows than cash flow information itself (SFAC \#1, para. 44). Empirical studies in the United States that test the FASB's assertion fall into two categories, namely, studies that examine capital market effects of accounting information and those that directly examine the ability of accounting information to predict future cash flows (or surrogates of future cash flows). ${ }^{3}$ However, these two categories always deal with the predicted values. The former employs the predicted values, as a proxy for market expectations, in order to measure the unexpected values of an accounting variable under consideration, while the latter uses the predicted values to evaluate the predictive ability of an accounting variable(s).

The basic assumption underlying research in the information content of earnings and earnings forecasting literature is that accounting earnings is a good surrogate of future cash flows. However, since the accounting earnings incorporates accounting accruals and excludes investment activities, it is only under certain (extreme) conditions that expected accounting earnings equal future cash flows (Watts and Zimmerman 1986). Furthermore, management's discretion in choosing accrual methods is also deemed to decrease reliability of earnings as a surrogate of operating cash flows (Healy 1985; Dechow et al. 1995; Guay et al 1996). Nevertheless, studies in the information content of cash flow data provide incon- sistent evidence (Neill et al. 1991). Early studies that employ simple cash flow measures (earnings plus depreciation) fail to detect information content of cash flows, while later studies that measure information content of operating cash flows find a significant association between cash flows and stock prices (Rayburn 1986; Bowen et al. 1987; Wilson 1987; Livnat and Zarowin 1990; among others).

Few studies on the usefulness of accounting information have been conducted in Indonesia. Most of these studies measure the information content of earnings in association with stock prices (capital market research) on the Jakarta Stock Exchange (JSX). These studies provide inconsistent evidence regarding the value of earnings in setting stock prices on the JSX (Setiawati 1995; Husnan et al. 1996; Hanafi 1997). Three possible reasons may be put forward for this inconclusive evidence, namely, inappropriate research methodology, an inefficient market, and valueless accounting information. As far as the research methodology, these studies may fail to appropriately specify window events, select variable measurement, or select a proxy of the market.

Husnan (1992) indicates that the efficiency of the JSX was still in weak form, but it has increased since 1990. Also, using 1991-1996 data, Sugiyanto (1998) finds consistent results with Husnan's (1992) that the Indonesian stock market was not efficient, at least in the semi-strong form. This finding, together with the fact that the JSX activities are still considered "thin activities," shows that the assumption of a semi-strong efficient market is violated.

\footnotetext{
${ }^{3}$ Based on the assumption that the financial statements' users use the best data available, where best is defined as most accurate, Brown (1993) states that the predictive ability and association studies are two sides of the same coin. This means that examining the value-relevance of accounting information using the association and predictive ability approaches should result in a similar conclusion (Brown 1993).
} 
Some possible reasons explain the lack of value-relevance in accounting information that may have cause the inconsistent results found in these early studies. For example, since the inflation rate in Indonesia is relatively high, it could decrease the value of historical cost-based earnings as a measure of a firm's performance (PSAK does not have an accounting standard for inflation or changing prices). Moreover, the lack of disclosures required by the Indonesian accounting standards (Sutton 1997; Saudagaran and Diga 1997) should also reduce the quality of accrual earnings.

Machfoedz (1994) measures the usefulness of accounting information in Indonesia based on 84 manufacturing firms listed on the JSX for the years of 19891992. Even though using firms listed on the JSX, his study does not directly measure the effect of accounting information on stock prices. Machfoedz defines the usefulness of accounting information in terms of an association between financial ratios (extracted from financial statements) and future earnings changes. He asserts that financial ratios significantly associate with a year ahead of earnings changes, but the association significantly decreases with two year ahead of earnings changes.

Three things can be noted from Machfoedz's study. First, since there is inconsistent evidence regarding the value of earnings in the JSX, relating the financial ratios and earnings may not reflect the way investors process accounting information. Second, the use of earnings changes as a benchmark of information usefulness assumes that information users (investors) follow a naive random walk model. Since there is no prior research in user response to accounting information in Indonesia, further study to validate this assumption is needed. Finally, under the EMH and CAPM theories, his study does not provide evidence concerning the valuerelevance of accounting information in asset valuation. In terms of the usefulness of accounting information as stated in the PSAK, his study does not directly provide evidence on the ability of accounting information to assess a firm's future cash flows.

Parawiyati and Baridwan (1998) evaluate the predictive ability of earnings and cash flows to predict future earnings and cash flows. They measure the predictive ability of earnings versus cash flows based on the degree of association (using linear regressions) between earnings (cash flows) and future earnings (cash flows). However, this study does not measure the real forecasterrors of their predictive model used in their study.

\section{Hypothesis Development}

Accrual earnings are based on two important accounting principles, namely, the revenue recognition and matching principles. The revenue recognition principle requires a firm to recognize revenues when it has performed all, or a substantial portion of, services that have to be rendered, and cash receipts from the transaction are reasonably certain. The matching principle requires a firm to recognize all expenses associated with revenues in the same period in which the revenues have been recognized. Since this accrual process is deemed to mitigate the timing and matching problems inherent in cash flows, it is believed that earnings more closely represent a firm's performance (Dechow 1995). ${ }^{4}$ Hence, studies in the usefulness of

\footnotetext{
${ }^{4}$ Since cash flows are presumed to be the main focus of most investors, firm performance here shows the ability (and the risk) of a firm to generate current and future cash flows.
} 
earnings (accrual based earnings) for investment decisions are based on the hypothesis that earnings is a good surrogate for a firm's future cash flows (Beaver 1968; Ball and Brown 1968; Easton 1985; among others).

However, since management usually has some discretion over the recognition of accruals, accrual earnings may be a noisy measure of the firm's performance. While the accounting conventions of objectivity and verifiability may limit the flexibility of management's discretion (Watts and Zimmerman 1986), they also may reduce the ability of earnings to reflect a firm's performance. Hence, the accrual process may result in a trade-off of information quality between reliability and relevance (SFAC \#2 para 90; Ball 1989). This condition leads to the possibility that earnings may become less reliable as a measure of a firm's performance than cash flow data (Dechow 1994). Dechow et al. (1995) examine a sample of firms to evaluate earnings management. They find that accruals that reverse in the subsequent year reflect earning manipulations.

Moreover, Rayburn (1986), Wilson (1986 and 1987), Bowen et al. (1987), and Livnat and Zarowin (1990) also document that cash flow data provide incremental information content beyond earnings. They measure the incremental information content based on the association between unexpected cash flows and stock returns. These findings are consistent with the argument supporting the issuance of standards in cash flow statement (SFAS \#95), cash flow information adds information contained in earnings (Wolk and Tearney 1997). Nevertheless, these studies do not provide evidence of the relative ability of earnings versus cash flows to assess a firm's future cash flows.
Sloan (1996) indicates that the persistence of earnings performance depends on the magnitudes of the cash and accruals components of earnings. The higher the accrual component, the lower the persistence of earnings performance, while the higher the cash flow component, the higher the persistence of earnings performance. Furthermore, the results of market-based studies of the incremental information content of earnings components indicate that the market reacts differently to various earning components (Fairfield et al. 1996; Strong and Walker 1993; Ohlson and Penman 1992).

The differences in cultural and economic factors that exist between the U.S. and Indonesia may cause different values to be assigned to the same piece of information. One example of economic factors that affect the value of accounting information is the impact of inflation rate on historical-based costing of accounting information. The inflation rate is a proxy of an economic condition that has been widely used in economic studies. Ndubizu (1992) and Doupnik and Salter (1995) find significant evidence supporting the dampening effect of inflation rates on the value of accounting information in various countries. The relatively high inflation rate (double digit) in Indonesia during this decade could decrease the benefits of a historical cost-based system of accounting. Accounting information may become less relevant under historical-based costing. High inflation rates will cause historical cost-based earnings to be overstated. Consequently, its predictive value decreases (Wolk and Tearney 1997). Therefore, cash flow data that are free from inflation effects should provide a better indication of future cash flows than earnings. 
Suprivadi-ThePredictiveAbility ofEarningsvsCashFlowDatatoPredictFutureCashFlows

The differences in the accounting standards between the U.S. and Indonesia should also affect the usefulness of accounting information. The lack of a core set of standards and comparability combined with differing interpretations of IAS (PSAK) (Sutton 1997) may decrease the usefulness of accounting information. For instance, management's discretion over the accrual process may not be fully disclosed to the public through the financial statements. Consequently, accrual earnings becomes a noisy measure of a firm's performance. Therefore, cash flow data that are free from the effects of management's discretion over accruals should provide a better indication of future cash flows than earnings. This leads to the following null hypothesis:

$H_{0}$ 1: Cash flow data do not outperform earnings as the predictor of a firm's future cash flows.

To examine whether earnings provide incremental information to assess future cash flows in the presence of cash flow variables, Finger (1994) combines earnings and cash flows as predictors of future cash flows. She finds evidence that earnings adds information to cash flows. Although the ability of earnings to assess future cash flows may be less relevant in Indonesia, earnings may still add relevant information. Therefore, combining earnings and cash flows in the forecasting model may increase the power of the model. This leads to the following null hypotheses:

$\mathrm{H}_{0}$ 2: A combination of cash flow data and earnings does not outperform either earnings or cash flow data alone as the predictor of a firm's future cash flows.

$H_{0} 3$ : When the forecasting model employs earnings and cash flow data as the explanatory variables, cash flow (earnings) data do not provide extra information over and above earnings (cash flow) data.

\section{Cash Flow Forecasting Models}

Testing the ability of earnings versus cash flows to predict future cash flows (the FASB's contention) requires models that employ either earnings or cash flows alone as a predictor of cash flows (Bowen et al. 1986; Greenberg et al 1986; Murdoch and Krause 1989, 1990; Finger 1994). Furthermore, to examine whether earnings provide incremental information to assess future cash flows in the presence of cash flow variables, Finger (1994) combines earnings and cash flows as predictors of future cash flows. ${ }^{5}$ The models employed in this study were developed based on these earlier models. In summary, there are three cash flow forecasting models used in this study. These models are presented in Equation 1.

${ }^{5}$ The argument supporting the issuance of a standard requiring a Cash Flow Statement (SFAS \#95) is that cash flow information adds to the information contained in earnings. This means that cash flow information does not eliminate the usefulness of earnings but it adds information to earnings. Therefore, Finger's model (1994) is consistent with the FASB assertion. 
Where,

$\mathrm{CFO}_{\mathrm{t}}=$ cash flows from operations

$\mathrm{CFO}_{\mathrm{t}-\mathrm{i}}=$ the lagged values of cash flows from operations

$\mathrm{EA}_{\mathrm{ti}}=$ the lagged values of earnings.

$\mathrm{t}=$ time variable measured semi-annually

$\mathrm{D} \quad=$ dummy variable to proxy different accounting standards, $\mathrm{D}=1$ for 1995-1997 financial data and $\mathrm{D}=0$, otherwise.

In this study, the lagged variables $t-1$ and $t-2$ (for semi-annual data) are used in Models (1), (2), and (3) to capture adjacent effects ( $t-1)$ and seasonal effects $(\mathrm{t}-2)$ of the independent variables on the CFO.

In this study, all variables used in the model will be extracted either from the balance sheet and income statement, or the statement of changes in the financial position or cash flows. Specifically, the variables are as follows (Neill et al. 1990; Wilson 1986, 1987; Livnat and Zarowin 1990).

- Cash Flows from Operations = Earnings before extraordinary items \pm Noncurrent Accruals \pm Current Accruals

- Current Accruals = the net changes in the working capital accounts except for changes in cash, marketable securities, and short-term debt.
- Noncurrent Accruals = Depreciation and Amortization + Adjustment for other noncurrent accruals.

- Earnings = Earnings before extraordinary items

The values of the variables used in the models are scaled by the total assets of the related firm at the beginning of the period (semi-annual period). The purpose of scaling the variables is to control for heteroscedasticity which may arise due to the level of economic activities that varies over time. Scaling by total assets transforms measures of different time periods into comparable measurements.

\section{Empirical Results}

\section{Sample and Descriptive Statistics}

The data used in this study were semiannual data for the 61 sample firms (manufacturing firms) listed in the JSX spanning the years 1990-1996. Initially, there are 72 firms which had all the data needed. From these firms, eleven firms were dropped as the result of checking for outliers.

This study performed an analysis that used the 1990-96 period data set that consisted of semi-annual data from the first semi-annual reporting period of 1990 to

Table 1. Descriptive Statistics for Variables Used in the Prediction Models Distributions of Pooled Cross-sectional Data for 61 Firms (Semi-annual Data 19901996)

\begin{tabular}{|l|c|c|c|c|c|c|c|c|}
\hline Variable & N & Mean & S.D. & Minimum & Maximum & Median & $\begin{array}{c}\text { Lower } \\
\text { Quartile }\end{array}$ & $\begin{array}{c}\text { Upper } \\
\text { Quartile }\end{array}$ \\
\hline CFO & 793 & 0.077 & 0.133 & -0.464 & 0.449 & 0.072 & 0.016 & 0.132 \\
EA & 793 & 0.081 & 0.107 & 0.014 & 0.763 & 0.054 & 0.043 & 0.078 \\
\hline
\end{tabular}

Note:

Variable definitions: $C F O=$ cash flows from operations; $E A=$ net income before extraordinary items.

The variables had each been deflated by total assets at the beginning of each period. 
Suprivadi-ThePredictiveAbilityofEarningsvsCashFlowDatatoPredictFutureCashFlows

Table 2. Pearson Correlations between Dependent Variable and Independent Variables Distribution of Correlations for 61 Firms (Semi-annual Data, 19901996)

\begin{tabular}{|l|c|c|c|c|}
\hline \multicolumn{1}{|c|}{$\mathbf{C F O}_{\mathbf{t}}$} & $\mathbf{C F O}_{\mathbf{t}-\mathbf{1}}$ & $\mathbf{C F O}_{\mathbf{t}-\mathbf{2}}$ & $\mathbf{E A}_{\mathbf{t}-\mathbf{1}}$ & $\mathbf{E A}_{\mathbf{t}-\mathbf{2}}$ \\
\hline Mean & -0.17 & 0.21 & 0.08 & 0.08 \\
S.D. & 0.34 & 0.47 & 0.32 & 0.29 \\
Maximum & 0.74 & 0.83 & 0.80 & 0.74 \\
Minimum & -0.78 & -0.69 & -0.55 & -0.55 \\
Median & -0.19 & 0.17 & 0.13 & 0.13 \\
Lower Quartile & -0.44 & -0.23 & -0.17 & -0.20 \\
Upper Quartile & -0.01 & 0.61 & 0.31 & 0.29 \\
\hline
\end{tabular}

the second semi-annual reporting period of 1996 (12 observations for each firm). The results of the regression (coefficient parameters) on 12 observations were then used to forecast cash flows from operations for the first semi-annual reporting period of 1997.

Table 1 presents the descriptive statistics of data for variables used in the models. The values of the variables have each been deflated by the total assets at the beginning of each period. Moreover, the distribution of contemporaneous correlation between cash flows from operations (the dependent variable for all forecasting models) and the independent variables is presented in Table 2 .

\section{Regression Results}

Three regression models were used to analyze the data. Cash flows from operations were the dependent variable for all regression models. The first model was called the cash flow model, while the second model was called the earnings model and the third model was called the earnings-cash flow model.

Since the earnings-cash flow model consists of cash flows and earnings as the regressors, analyzing this model is expected to provide an answer on the valuerelevance of cash flows versus earnings in predicting a firm's future cash flows. Furthermore, analysis of this model can also be used to test whether earnings (cash flows) provide incremental predictive ability in the presence of cash flows (earnings). Hence, further evaluation of the cash flow and earnings models is expected to strengthen the results of analyzing the earnings-cash flow model. Thus, in the following parts, the results of regressing the earnings-cash flow model are presented first.

\section{The Earnings-Cash Flow Model (Model 3)}

Table 3 summarizes the results of estimating the earnings-cash flow model based on firm-specific regressions. The results provide an early indication that cash flows from operations may outperform earnings as a predictor of a firm's future cash flows. The results indicate that the model is robust for $12(20 \%)$ and 22 (36\%) firms at the 0.05 and 0.10 . The adjusted $\mathrm{R}^{2}$ ranges from the lowest of 0.45 to the highest of 0.74 with the mean of 
GadjahMadaInternationalJournal ofBusiness, September1999, Vol.1,No.2

Table 3. Regression Results - Distribution of Adjusted $\mathbf{R}^{2}$ and Other Statistical Measures for 61 Firms (Semi-annual Data, 1990-1996)

Model 3: CFO $_{t}=b_{0}+b_{1}$ CFO $_{t-1}+b_{2} \mathbf{C F O}_{t-2}+b_{3} \mathbf{E A}_{t-1}+b_{4} \mathbf{E A}_{t-2}+b_{4} \mathbf{D}+e$

\begin{tabular}{|c|c|c|c|c|c|c|}
\hline \multirow{6}{*}{\multicolumn{2}{|c|}{$\begin{array}{l}\text { Mean Adjusted } \mathrm{R}^{2} \\
\text { Maximum Adjusted } \mathrm{R}^{2} \\
\text { Minimum Adjusted } \mathrm{R}^{2} \\
\text { Median Adjusted } \mathrm{R}^{2} \\
\text { Lower Quartile Adjusted } \mathrm{R}^{2} \\
\text { Upper Quartile Adjusted } \mathrm{R}^{2}\end{array}$}} & 0.34 & & \\
\hline & & 0.74 & & & & \multirow{5}{*}{$22(36 \%)$} \\
\hline & & -0.45 & \multirow{3}{*}{\multicolumn{3}{|c|}{ F-values at the 0.05 Level }} & \\
\hline & & 0.40 & & & & \\
\hline & & 0.12 & & & & \\
\hline & & 0.43 & \multicolumn{3}{|c|}{ F-values at the 0.10 Level } & \\
\hline $\begin{array}{l}\text { Number of } \\
\text { Firms with } b_{i} \bullet 0\end{array}$ & Intercp. & $\mathrm{CFO}_{t}$ & $\mathrm{CFO}_{\mathrm{t}-2}$ & $\mathbf{E A}_{t-1}$ & $\mathbf{E A}_{t-2}$ & D \\
\hline at the 0.05 level & $14(23 \%)$ & $16(26 c$ & $25(41 \%)$ & $3(5 \%)$ & $8(13 \%)$ & $11(18 \%)$ \\
\hline at the 0.10 level & $20(33 \%)$ & $24(39)^{\circ}$ & $34(56 \%)$ & $11(18 \%)$ & $13(21 \%)$ & $22(36 \%)$ \\
\hline
\end{tabular}

0.34 and median of 0.40 . For the coefficient parameters of cash flows from operations, lags 1 and 2 cash flows from operations are significant for $16(26 \%)$ and 24 (39\%) firms at the 0.05 level, and 25 $(41 \%)$ and $34(56 \%)$ firms at the 0.10 level. In comparison, lags 1 and 2 earnings are significant for $3(5 \%)$ and $11(18 \%)$ firms at the 0.05 level, and $8(13 \%)$ and 13 (21\%) firms at the 0.10 level. Finally, the dummy variable of changes in accounting standards is significant for $11(18 \%)$ and for $13(21 \%)$ firms at the 0.05 and 0.10 levels.

\section{The Cash Flow Model (Model 1)}

Table 4 summarizes the results of estimating the cash flow model with lags 1 and 2 cash flows from operations and a dummy as independent variables. The results of firm-specific regressions indicate that $20(33 \%)$ and $28(46 \%)$ of the firms' $F$ values are significant at the 0.05 and 0.10 . The mean adjusted $R^{2}$ is 0.31 with the highest adjusted $R^{2}$ of 0.62 , the lowest of -0.16 , and the median of 0.29 . In terms of significant coefficient parameters at
0.05 and 0.10 , lag 2 cash flows from operations is significant for $28(46 \%)$ and 35 (57\%) firms, while lag 1 cash flows from operations is significant for 17 (28\%) and 27 (44\%) firms. The dummy variable is significant for $28 \%$ and $33 \%$ of the firms at the 0.05 and 0.10 level, respectively.

\section{The Earnings Model (Model 2)}

Table 5 presents the results of estimating the earnings model with lags 1 and 2 earnings and a dummy as the independent variables. The results of firm-specific regressions indicate that $8(13 \%)$ and 11 (18\%) of the firms exhibit significant overall regression at the 0.05 and 0.10 . The mean adjusted $R^{2}$ is 0.12 with the highest adjusted $R^{2}$ of 0.55 , the lowest of -0.33 , and the median of 0.03 . In terms of significant coefficient parameters at 0.05 and 0.10 , lag 2 earnings is significant for 10 $(17 \%)$ and $19(31 \%)$ firms, while lag 1 earnings is significant for 7 (12\%) and 13 (21\%) firms. The dummy variable is significant for $18 \%$ and $21 \%$ of the firms at the 0.05 and 0.10 level, respectively. 
Suprivadi-ThePredictiveAbilityofEarningsvsCashFlowDatatoPredictFutureCashFlows

Table 4. Regression Results - Distribution of Adjusted $\mathbf{R}^{\mathbf{2}}$ and Other Statistical Measures for 61 Firms (Semi-annual Data, 1990-1996)

Model 1: $\mathrm{CFO}_{t}=b_{0}+b_{1}$ CFO $_{t-1}+b_{2} \mathbf{C F O}_{t-2}+b_{3} D+e$

\begin{tabular}{|c|c|c|c|c|c|}
\hline \multicolumn{2}{|l|}{ Mean Adjusted $\mathrm{R}^{2}$} & 0.31 & \multicolumn{2}{|c|}{ Number of Firms with Significant } & \\
\hline \multicolumn{2}{|c|}{ Maximum Adjusted $\mathrm{R}^{2}$} & 0.62 & \multicolumn{2}{|c|}{ F-values at the 0.05 Level } & $20(33 \%)$ \\
\hline \multicolumn{2}{|c|}{ Minimum Adjusted $\mathrm{R}^{2}$} & -0.16 & & & \\
\hline \multicolumn{2}{|l|}{ Median Adjusted R ${ }^{2}$} & 0.29 & \multicolumn{2}{|c|}{ Number of Firms with Significant } & \\
\hline \multirow{2}{*}{\multicolumn{2}{|c|}{ Upper Quartile Adjusted R ${ }^{2}$}} & 0.09 & \multirow{2}{*}{\multicolumn{2}{|c|}{ F-values at the 0.10 Level }} & $28(46 \%)$ \\
\hline & & 0.37 & & & \\
\hline $\begin{array}{c}\text { Number of } \\
\text { Firms with } b_{i} \bullet 0\end{array}$ & \multicolumn{2}{|c|}{ Intercept } & $\mathrm{CFO}_{\mathrm{t}-1}$ & $\mathrm{CFO}_{\mathrm{t}-2}$ & D \\
\hline at the 0.05 level & \multicolumn{2}{|c|}{$31(51 \%)$} & $17(28 \%)$ & $28(46 \%)$ & $17(28 \%)$ \\
\hline at the 0.10 level & \multicolumn{2}{|c|}{$36(59 \%)$} & $27(44 \%)$ & $35(57 \%)$ & $20(33 \%)$ \\
\hline
\end{tabular}

Table 5. Regression Results - Distribution of Adjusted $\mathbf{R}^{2}$ and Other Statistical Measures for 61 Firms (Semi-annual Data, 1990-1996)

Model 2: $\mathbf{C F O}_{t}=b_{0}+b_{1} \mathbf{E A}_{t-1}+b_{2} \mathbf{E A}_{t-2}+b_{3} \mathbf{D}+e$

\begin{tabular}{|c|c|c|c|c|c|}
\hline \multirow{6}{*}{\multicolumn{2}{|c|}{$\begin{array}{l}\text { Mean Adjusted } \mathrm{R}^{2} \\
\text { Maximum Adjusted } \mathrm{R}^{2} \\
\text { Minimum Adjusted } \mathrm{R}^{2} \\
\text { Median Adjusted } \mathrm{R}^{2} \\
\text { Lower Quartile Adjusted } \mathrm{R}^{2} \\
\text { Upper Quartile Adjusted } \mathrm{R}^{2}\end{array}$}} & 0.12 & \multirow{2}{*}{\multicolumn{2}{|c|}{$\begin{array}{l}\text { Number of Firms with Significant } \\
\text { F-values at the } 0.05 \text { Level }\end{array}$}} & \\
\hline & & 0.55 & & & $8(13 \%)$ \\
\hline & & -0.33 & \multirow{3}{*}{\multicolumn{2}{|c|}{ Number of Firms with Significant }} & \\
\hline & & 0.03 & & & \\
\hline & & -0.16 & & 10 Level & $11(18 \%)$ \\
\hline & & 0.11 & & & \\
\hline $\begin{array}{c}\text { Number of } \\
\text { Firms with } b_{I} \bullet 0\end{array}$ & \multicolumn{2}{|c|}{ Intercept } & $\mathbf{E} \mathbf{A}_{t-1}$ & $\mathbf{E} \mathbf{A}_{t-2}$ & D \\
\hline at the 0.05 level & \multicolumn{2}{|c|}{$10(17 \%)$} & $7(12 \%)$ & $10(17 \%)$ & $11(18 \%)$ \\
\hline at the 0.10 level & \multicolumn{2}{|c|}{$18(30 \%)$} & $13(21 \%)$ & $19(31 \%)$ & $13(21 \%)$ \\
\hline
\end{tabular}

Comparing the regression results of the cash flow, earnings, and earnings-cash flow models provides an early indication that cash flows from operations outperform earnings as the predictor of future cash flows. Furthermore, the marginal increase in adjusted $\mathrm{R}^{2}$ for the earnings-cash flow model compared to the cash flow model also indicates that earnings adds little to the overall explanatory power. The average adjusted $\mathrm{R}^{2}$ for the cash flow model is 0.31 , the earnings model is 0.12 , and the earnings-cash flow model is 0.34 . The dummy variable is only significant for some firms. This indicates that the new accounting standards may not have the same effects for all sample firms. 
GadjahMadaInternationalJournal ofBusiness, September1999, Vol.1,No.2

Table 6. Distribution of Absolute Percentage Errors (APE) ${ }^{\mathrm{d}}$

\begin{tabular}{|l|c|c|c|}
\hline & Model 1 & Model 2 & Model 3 \\
\hline Mean (MAPE) & 0.64 & 0.82 & 0.62 \\
S.D. & 0.37 & 0.59 & 0.40 \\
Maximum & 1.98 & 2.88 & 2.73 \\
Minimum & 0.01 & 0.09 & 0.13 \\
Median & 0.66 & 0.60 & 0.58 \\
Lower Quartile & 0.37 & 0.45 & 0.37 \\
Upper Quartile & 0.80 & 1.03 & 0.79 \\
\hline Normal Distribution & & & \\
Test (W) & $0.96 * *$ & $0.83 *$ & $0.82 *$ \\
\hline
\end{tabular}

${ }^{d}$ APE is defined as the absolute value of (Actual CFO -Forecast CFO)/Actual CFO.

* significant at 0.01 ;* significant at 0.05

\section{Predictive Ability Results}

One-step-ahead semi-annual cash flow predictions are generated in an ex ante fashion (out-of-sample forecast) for the five cash flow prediction models. The results of the regressions are used to predict cash flows from operations for the first semi-annual reporting period of 1997. In terms of predictive ability, one error metric, absolute percentage error (APE) is computed. APE is defined as the absolute value of the difference between the actual and forecast value divided by the actual value of cash flows from operations. Predictive ability of one model compared to other models (among models) is determined using mean absolute percentage error (MAPE).

Table 6 summarizes the distribution of absolute percentage error from three regression models. Normal distribution tests indicate that APEs resulting from each of the three models are normally distributed. The results of the tests show that the probabilities of normal distribution for APEs are statistically significant at 0.01 for the earnings and earnings-cash flow models, and at 0.05 for the cash flow model. Therefore, a t- or an F-test is employed to test the difference between two means or among means of APEs.

\section{Hypothesis Tests}

Hypotheses 1 and 2 were tested by comparing MAPEs resulting from all three models. Hypothesis 3 is tested by evaluating the earnings-cash flow model to determine whether subsets of coefficient parameters of cash flows and of earnings are significantly different from zero. In terms of variable contribution into the forecasting model, Hypothesis 3 evaluates the usefulness of cash flow data versus earnings when they are used together in the forecasting model. Therefore, since Hypotheses 1 and 2 test the predictive ability of either cash flow or earnings data alone, it is expected that testing Hypotheses 1,2, and 3 will result in a similar conclusion. Specifically, since testing Hypothesis 3 indirectly can also test Hypotheses 1 and 
Suprivadi-ThePredictiveAbility ofEarningsvsCashFlowDatatoPredictFutureCashFlows

2, further tests of Hypotheses 1 and 2 is purported to strengthen the results of testing Hypothesis 3. Hence, in the following, the result of testing Hypothesis 3 is presented first.

An $F$ test ("partial" $F$ test) is employed to measure whether subset of coefficients of cash flows (earnings) in the model is equal to zero. An F-statistic to test Hypothesis 3 is calculated based on the residual sum of squares resulting from the full model (the original earnings-cash flow model) and the reduced model. The reduced model is constructed based on the earnings-cash flow model with the variables stated in the null hypothesis removed from the model. Specifically, testing the contribution of cash flows (earnings) is performed by comparing the earnings-cash flow model and the earnings model (the cash flow model) to determine whether the earnings-cash flow model is significantly better than the earnings model (the cash flow model).

The distribution of F-values to test Hypothesis 3 (for both firm-specific and pooled cross-sectional regressions) is presented in Table 7. These measures are used to test Hypothesis 3, whether cash flows (earnings) provide extra information over and above earnings (cash flows). Since there are two cash flow and earnings variables used in Model 3 (lags 1 and 2 for each variable), a test of Hypothesis 3 is performed by evaluating the contribution of lags 1 and 2 cash flows or earnings simultaneously.

The results of the firm-specific regressions indicate that cash flows are superior to earnings. For the period under

Table 7. Test of Hypothesis 3 - Distribution of F-value for Testing $\mathrm{H}_{\mathbf{0}}$ as Stated Below Model 3: $\mathbf{C F O}_{\mathrm{t}}=\mathrm{b}_{0}+\mathrm{b}_{1} \mathbf{C F O}_{\mathrm{t}-1}+\mathrm{b}_{2} \mathbf{C F O}_{\mathrm{t}-2}+\mathrm{b}_{3} \mathbf{E A}_{\mathrm{t}-1}+\mathrm{b}_{4} \mathbf{E A}_{\mathrm{t}-2}+\mathrm{b}_{5} \mathbf{D}+\mathrm{e}$ The reduced models of Model 3 for $\mathrm{H}_{0}$ of $\mathrm{b}_{1}=\mathrm{b}_{2}=0$ 0: $\mathbf{C F O}_{\mathrm{t}}=\mathrm{b}_{0}+\mathrm{b}_{3} \mathbf{E A}_{\mathrm{t}-1}+\mathrm{b}_{4} \mathbf{E A}_{\mathrm{t}-2}+\mathrm{b}_{5} \mathbf{D}+\mathrm{e}($ Model 2) $b_{3}=b_{4}=0:$ CFO $_{t}=b_{0}+b_{1}$ CFO $t-1+b_{2}$ CFO $_{t-2}+b_{5}$ D $+e($ Model 1)

\begin{tabular}{|l|r|r|}
\hline & $\mathrm{b}_{\mathbf{1}}=\mathrm{b}_{\mathbf{2}}=\mathbf{0}$ & $\mathrm{b}_{\mathbf{3}}=\mathrm{b}_{\mathbf{4}}=\mathbf{0}$ \\
\hline Mean F-valuec $^{\mathrm{c}}$ & 3.98 & 1.64 \\
Maximum F-value & 15.83 & 6.45 \\
Minimum F-value & 0.22 & 0.01 \\
Median F-value & 3.46 & 0.66 \\
Lower Quartile F-value & 0.85 & 0.37 \\
Upper Quartile F-value & 5.06 & 2.97 \\
\hline Number of Firms with Significant F at 0.05 & $20(33 \%)$ & $5(8 \%)$ \\
Number of Firms with Significant F at 0.10 & $36(59 \%)$ & $15(25 \%)$ \\
\hline
\end{tabular}

${ }^{\mathrm{c}} \mathrm{F}$-value is calculated using the following formula:

$\mathrm{F}=\left(\left(\mathrm{SSE}_{\mathrm{R}}-\mathrm{SSE}_{\mathrm{F}}\right) /(\mathrm{K}-\mathrm{L}+1)\right) /\left(\mathrm{SSE}_{\mathrm{F}} /(\mathrm{n}-\mathrm{K}-1)\right)$, where $\mathrm{SSE}_{\mathrm{R}}=$ sum of squared errors from the reduced model; $\mathrm{SSE}_{\mathrm{F}}=$ sum of squared errors from the full model;

$\mathrm{K}=$ the number of the independent variables used in the full model, $\mathrm{L}=$ the number of the independent variables used in the reduced model (including the intercept), and

$\mathrm{n}=$ the number of observations. 
examination, $20(33 \%)$ and 36 (59\%) firms reject the null hypothesis that cash flows do not provide extra information over and above earnings at the 0.05 and 0.10 levels, respectively. In comparison, only 5 (8\%) and $15(25 \%)$ firms reject the null hypothesis that earnings does not provide extra information over and above cash flows at the 0.05 and 0.10 levels, respectively.

Hypothesis 1 was also constructed to address the first specific research question. This hypothesis tests the predictive ability of cash flow versus earnings data when each is employed alone in the model. Hypothesis 2 is developed to measure the relative predictive abilities of cash flow and earnings data when they are used together. The difference between Hypotheses 2 and 3 is that while Hypothesis 3 evaluates the contribution of each cash flow versus earnings, Hypothesis 2 examines the predictive ability of both cash flows and earnings. Hence, it was expected that the results of testing Hypotheses 1 and 2 would be consistent with the results of Hypothesis 3 tests.

Table 8. Tests of Hypotheses 1 and 2 Comparison of Mean Absolute Percentage Errors (MAPE) of CFO Predictions on June 30, 1997

\begin{tabular}{|l|c|c|c|}
\hline APE on June 30, 1997 & Model 1 & Model 2 & Model 3 \\
\hline MAPE & 0.64 & 0.82 & 0.62 \\
S.D. & 0.37 & 0.59 & 0.40 \\
Maximum & 1.98 & 2.88 & 2.73 \\
Minimum & 0.01 & 0.09 & 0.13 \\
Median & 0.66 & 0.60 & 0.58 \\
Lower Quartile & 0.37 & 0.45 & 0.37 \\
Upper Quartile & 0.80 & 1.03 & 0.79 \\
\hline Hypothesis Tests of MAPE Differences & & \\
\hline \multicolumn{2}{|c|}{} & $\mathbf{6 / 3 0 / 9 7}$ & \\
\multicolumn{2}{|l|}{ 1. Models 1 and 2 } & t-value & Lower APE \\
2. Models 1 and 3 & 0.23 & & $36(59 \%)$ \\
3. Models 2 and 3 & $2.34 * *$ & & $36(59 \%)$ \\
4. Models 1, 2, and 3 & & \\
\hline
\end{tabular}

${ }^{\mathrm{h}}$ Comparison of the magnitude of APE between two models.

The numbers appearing in this column show the number of firms (percentage) from the lower MAPE model which have lower APE.

For example, in the comparison of Models 1 and 2, Model 1 has a lower MAPE. Hence, 36 (59\%) in the row of Models 1 and 2 means that 36 firms (59\%) out of the sample firms (from a total of 61 firms) has lower APE under the prediction of Model 1 than that of Model 2.

** significant at 0.05 
Hypothesis 1 is tested by comparing MAPEs from the cash flow and earnings models, while Hypothesis 2 is tested by comparing MAPEs from the cash flow, earnings, and earnings-cash flow models. A t-test is employed to statistically measure MAPE differences resulting from two models and an F-test is used to statistically measure MAPE differences resulting from more than two models. Table 8 presents the results of MAPE comparisons including the statistical tests for Hypotheses 1 and 2.

The result of testing Hypothesis 1 that the MAPE of the cash flow model (0.64) is significantly different from that of the earnings model $(0.82)$ at the 0.05 level ( $\mathrm{t}$-value $=2.36$ ). Consistently, looking at the APE for each firm, the cash flow model outperforms (has lower APE than) the earnings model in 36 (59\%) firms, while the earnings model outperforms (has lower APE than) the cash flow model in 25 (41\%) firms. The result supports the expectation as stated in Hypothesis 1, cash flow data provide better information to forecast future cash flows than earnings.

Hypothesis 2 is tested by comparing MAPEs from all three models. Pairwise ttest comparisons indicate that the cash flow model (0.64) is not significantly different from that of the earnings-cash flow model (0.62), while the earnings model $(0.82)$ is significantly different from that of the earnings-cash flow model (0.62) at the 0.05 level (t-value $=2.34)$. Furthermore, $36(59 \%)$ firms have a lower APE as measured by the earnings-cash flow model than when only cash flow is included. On the other side, $25(41 \%)$ firms have a lower APE under the earnings model than the earnings-cash flow model. As expected, the results of comparing the three models simultaneously also support the expectation embodied in Hypothesis 2. The
MAPEs from these three models are significantly different at $0.05(\mathrm{~F}$-value $=3.53)$ at which the earnings model has the highest MAPE. This result indicates that earnings adds little to the ability of cash flows to predict future cash flows.

\section{Conclusion}

In general, empirical analyses performed in this study provided results supporting the proposed hypothesis that cash flow data provided better information to assess future cash flows than earnings data. The results of testing Hypothesis 3 on a firm-specific level indicated that cash flows significantly provided extra information over and above earnings for 59 percent of the sample firms while earnings was significantly found in 25 percent of the sample firms. The results of testing Hypotheses 1 and 2 provided supporting evidence on the results of testing Hypothesis 3.

Furthermore, lag 2 cash flows significantly outperformed lag 2 earnings, while lag 1 cash flows slightly dominated lag 1 earnings in three regression models. This result indicated that the effects of seasonal factors on future cash flows were more severe than those of adjacent factors. In terms of the predictive ability, cash flow and earnings combined exhibited the lowest MAPE and significantly dominated the earnings model but not the cash flow model.

This study contributes to the literature of the usefulness of accounting information study in three folds. First, this study examines the relevant variables that can be used by investors in forming expectations of a firm's future cash flows. A good expectation model is very important to a growing interest in capital-marketbased research in Indonesia (the JSX), since an accurate expectation model will 
yield a stronger information content study. Second, this study provides information about the behavior of feasible cash flow expectation models and the properties of Indonesian accounting information that may be useful for future research. Finally, this also provides evidence of - or at least it provides a basis for evaluating - the validity of the KPSAK assertion regarding the ability of accounting information to assess future cash flows.

The use of the univariate and multivariate models (Models 1, 2, and 3) based on a firm-specific may provide alternative evidence on the properties of accounting information. However, the limited timeseries data used may constrain the generalizability of the results. Nevertheless, at least it is expected that this study will provide a general framework in using accounting information to forecast future cash flows so that when more data are available, the models used in the study will be reliable.

Since the statement of cash flows is not readily available for the period before 1995, some cash flows from operations are calculated using information from the balance sheet and income statement. This condition may affect the validity of the results. However, the use of the same procedures to compute cash flows from operations stated in PSAK \#2 (Indonesian Accounting Standard on the Cash Flow Statements) in this study may minimize this problem.
This study employs manufacturing firms only as sample firms. The sampling criteria may affect the generalizability of the results. Therefore, future research is necessary to evaluate the robustness of the results to other populations of firms (nonmanufacturing firms). Furthermore, additional refinements of the prediction models on an industry-specific basis may further enhance the predictive power of the cash flow forecasting models.

The robustness of the results can also be evaluated by using an alternative deflator of earnings and cash flows as suggested by Finger (1994). This provides opportunity to extend this study by employing other deflators of variables used in the model. Such alternative deflators include consumer price index (CPI) and market value of the firms. Further extensions include disaggregating cash flow variables into operating, investing, and financing components in order to measure the predictive ability of disclosures prescribed by PSAK \# 2. Disaggregation of current accruals into their components can also be used to evaluate various information extracted from the accrual process. Finally, when data become available, analysis of considerably longer time-series databases may improve the predictive ability of the models. Also, this analysis can be used to further evaluate the timeseries properties of semi-annual cash flow data and the impact of structural changes on the time-series properties. 
Supriadi-ThePredictiveAbilityofEarningsvsCashFlowDatatoPredictFutureCashFlows

\section{References}

Ashton, R. 1974. The predictive-ability criterion and user prediction models. The Accounting Review (October): 719-32.

Ball, R., 1992. The earnings-price anomaly. Journal of Accounting and Economics, 15: $319-45$.

and P. Brown. 1968. An empirical evaluation of accounting income numbers. Journal of Accounting Research (Autumn): 159-77.

Bathke, Jr. A. W., and K. S. Lorek. 1984. The relationship between time-series models and the security market's expectation of quarterly earnings. The Accounting Review: 163-76.

Beaver, W. H., and P. A. Griffin, and W.R. Landsman. 1982. The incremental information content of replacement cost earnings. Journal of Accounting and Economics (July): 15-39.

Bernard, V. L., and T. L. Stober. 1989. predictive ability as a criterion for the evaluation of accounting data. The Accounting Review (October): 624-52.

, and J. Thomas. 1990. Evidence that stock prices do not fully reflect the implication of current earnings for future earnings. Journal of Accounting and Economics (December): 305-340.

Bowen, R. M., D. Burgstahler, and L. A. Daley. 1986. Evidence on the relationships between earnings and various measures of cash flows. The Accounting Review (October): 713-25.

, D. Burgstahler, and L. A. Daley. 1987. The incremental information content of accrual versus cash flows. The Accounting Review (October): 723-47.

Brown, L. D. 1993. Earnings forecasting research: Its implication for capital market research. International Journal of Forecasting 9: 295-320.

Brown, L. D., and M. S. Rozeff. 1979. Univariate time-series models of quarterly accounting earnings per share: A proposed model. Journal of Accounting Research: 179-89.

Chaney, P. K., D. C. Jeter, and C. M. Lewis. 1996. The use of Accruals in Income smoothing: A Permanent Earnings Hypothesis. Working Paper. Vanderbilt University.

Cooke, T. E., and R. S. O. Wallace. 1990. Financial disclosure regulation and its environment: A review and further analysis. Journal of Accounting and Public Policy (9): 79-110.

Dechow, P. M. 1994. Accounting earnings and cash flows as measures of firm performance: The role of accounting accruals. Journal of Accounting and Economics: 342. 
Dechow, P. M., R. G. Sloan, and A. P. Sweeney. 1995. Detecting earnings management. The Accounting Review 70: 193-225.

Doupnik, T. S., and S. B. Salter. 1995. External environment, culture, and accounting practice: A preliminary test of a general model of international accounting development. The International Journal of Accounting (30): 189-207.

Easton, P. 1985. Accounting Earnings and Security Valuation: Empirical Evidence of the Fundamental Links. Journal of Accounting Research (Supplement): 54-77.

Fairfield, P. M., R. J. Sweeney, and T. L. Yohn. 1996. Accounting classification and the predictive content of earnings. The Accounting Review (July): 337-55.

Financial Accounting Standards Board. 1978. Statement of Financial Accounting Concepts No. 1: Objectives of Financial Reporting by Business Enterprises. Stamford, CT: FASB.

Finger, C. A. 1994. The ability of earnings to predict future earnings and cash flow. Journal of Accounting Research (Autumn): 210-23.

Foster, G. 1977. Quarterly accounting data: Time-series properties and predictive ability results. The Accounting Review (January): 1-21.

Greenberg, R. R., G. L. Johson, and K. Ramesh. 1986. Earnings versus cash flow as a predictor of future cash flow Mmasures. Journal of Accounting, Auditing, and Finance: 266-77.

Guay, W. R., S. P. Kothari, and R. L. Watts. 1996. A Market-Based Evaluation of Discretionary-Accrual Models. Working Paper. University of Rochester, N.Y.

Hanafi, M. 1997. Informasi laporan keuangan: Studi kasus pada emiten BEJ. KELOLA Gadjah Mada University journal of Business (September) 16: 74-87.

Healy, P. M. 1985. The effect of bonus schemes on accounting decisions. The Journal of Accounting and Economics (7):85-107.

Husnan, S. 1992. Effisiensi pasar modal Indonesia. Jurnal Ekonomi Indonesia (April): 2534.

M. Hanafi, and A. Wibowo. 1996. Dampak pengumuman laporan keuangan terhadap kegiatan perdagangan saham dan variabilitas tingkat keuntungan. Kelola Gadjah Mada University Business Review 11 (May). Yogyakarta: Master of Management, G.M.U.

Ikatan Akuntan Indonesia (IAI). 1995. Pernyataan Standar Akuntansi Keuangan. Buku 1 dan 2. Jakarta, Indonesia.

Lev, B. 1989. On the usefulness of earnings and earnings research: Lessons and directions from two decades of empirical research. Journal of Accounting Research (Supplement): $153-210$.

Livnat, J., and P. Zarowin. 1990. The incremental information content of cash flow components. Journal of Accounting and Economics (May): 25-46. 
Suprijadi-ThePredictiveAbilityofEarningsvsCashFlowDatatoPredictFutureCashFlows

Lorek, K. S. 1979. Predicting annual net earnings with quarterly earnings time-series models. Journal of Accounting Research: 190-204.

, T. F. Schaefer, and G.L. Willinger. 1993. Time-series properties and predictive ability of funds flow variables. The Accounting Review (January): 151-63. , and G. L. Willinger. 1996. A multivariate time-series prediction model for cashflow data. The Accounting Review (January): 81-101.

Machfoedz, M. 1994. The Usefulness of Financial Ratios in Indonesia (Unpublished Dissertation). University of Kentucky.

Murdoch, B., and P. Krause. 1989. An empirical investigation of the predictive power of accrual and cash flow data in forecasting operating cash flow. Akron Business and Economics Review (Fall): 100-13.

1990. Further evidence on the comparative ability of accounting data to predict operating cash flows. The Mid-Atlantic Journal of Business (Winter): 1-13.

Neill, J. D. et al. 1991. The usefulness of cash flow data: A review and synthesis. Journal of Accounting Literature (Fall): 117-50.

Ndubizu, G. A. 1992. Accounting disclosure methods and economic development: A criterion for globalizing capital markets. The International Journal of Accounting (27): 151-63.

Ohlson, J. 1990. A synthesis of security valuation theory and the role of dividends, cash flows, and earnings. Contemporary Accounting Research (Spring): 648-76.

Pariwayati, and Z. Baridwan. 1998. Kemampuan laba dan arus kas dalam memprediksi laba dan arus kas perusahaan go publik di Indonesia. Jurnal Riset Akuntansi Indonesia. Vol. 1 No. 1. Januari: 1-11.

Rayburn, J. 1986. The association of operating cash Flow and accruals with security returns. Journal of Accounting Research (Supplement): 112-33.

Saudagaran, S. M., and J. G. Diga. 1997. Financial reporting in emerging capital markets: Characteristics and policy issues. Accounting Horizons (June): 41-64.

Setiawati, L. (1995). Kandungan Nilai Informasi Pengumuman Laba: Studi Kasus pada Bursa Efek Jakarta. (Unpublished Thesis S1). Yogyakarta: Faculty of Economics, G.M.U.

Sloan, R. G. 1996. Do stock prices fully reflect information in accruals and cash flows about future earnings? The Accounting Review (July): 289-316.

Sugiyanto, C. 1998. Price linkages in selected Indonesian financial market. Kelola Gadjah Mada University Business Review 17 (January): 50-60.

Supriyadi. 1998. The Association between Accounting Information and Future Cash Flows: An Indonesian Case Study (Unpublished Dissertation). University Of Kentucky. 
Sutton, M. H. 1997. Financial reporting in U.S. capital markets: International dimensions. Accounting Horizons (June): 96-102.

Watts, R. L., and J. L. Zimmerman. 1986. Positive Accounting Theory. New Jersey: Prentice-Hall, Inc.

Watts, R. L., and R. W. Leftwich. 1977. The time-series of annual accounting earnings. Journal of Accounting Research: 253-71.

Wilson, G. P. 1986. The relative information content of accruals and cash flows: Combined evidence at the earnings announcement and annual report release date. Journal of Accounting Research (Supplement): 165-200.

1987. The incremental information content of funds components of earnings after controlling for earnings. The Accounting Review (April): 293-322.

Wolk, H. I., and M. G. Tearney. 1997. Accounting Theory: A Conceptual and Institutional Approach. 4 ed. Cincinnati: South Western College Publishing Co. 